\title{
Subcontracting and vertical integration in the Spanish cotton industry
}

\author{
By JOAN R. ROSÉS
}

This paper examines changes in the organization of the Spanish cotton industry from 1736 to 1860 in its core region of Catalonia. As the Spanish cotton industry adopted the most modern technology available and experienced the transition to the factory system, cotton spinning and weaving mills became increasingly vertically integrated. Asset specificity, more than other factors, explains this tendency towards vertical integration. The probability of a firm being vertically integrated was higher among firms located in districts with high concentration ratios, and rose with size and the use of modern machinery. At the same time, subcontracting predominated in other phases of production and distribution, where transaction costs appear to be less important.

$\mathrm{T}$

he organizational structure of the cotton industry has attracted much scholarly attention, as it has been regarded as one of the key factors behind the international competitiveness of the industry. ${ }^{2}$ On the one hand, Lazonick and others have condemned the reliance of Lancashire on vertically specialized (singlephase) firms and its adverse consequences for coordinated investment in new technologies, transport costs, and decision-making. ${ }^{3}$ On the other hand, a number of authors have been highly sceptical of this interpretation of the advantages of vertical integration. ${ }^{4}$ In particular, it has been shown that the alleged benefits of vertical integration rarely manifested themselves in terms of superior international competitiveness or profitability. ${ }^{5}$

Differences in the business structures of cotton textile industries around the world emerged during the nineteenth century. By the 1850s, English and French cotton firms were mainly vertically specialized; whereas in the United States, Germany, and Spain, cotton firms were mostly vertically structured, combining spinning and weaving. ${ }^{6}$ Even within the same country or region, some firms vertically integrated cotton spinning and weaving while others preferred to put their yarn onto the market and, hence, were specialized. For example, within Lancashire, vertical integration was more common among cotton mills producing

\footnotetext{
${ }^{1}$ The author gratefully acknowledges the very useful comments and suggestions received from three anonymous referees, Mar Rubio, and the participants at the European Business History Association Conference (Barcelona) and the Global Economic History Network Meeting (Osaka), particularly those of his discussants on these occasions, Mary B. Rose and Masaki Nakabayashi. The Spanish Ministry of Education (Grants SEC 2002-01595 and SEJ2006-08188/ECON) supported this research. The usual disclaimer applies.

${ }^{2}$ A review of the literature is available in Jeremy, 'Organization'.

${ }^{3}$ See Lazonick, 'Industrial organization', and Mass and Lazonick, 'British cotton industry'.

${ }^{4}$ Perry ('Vertical integration', p. 185) defines vertical integration as the elimination of trade or contractual exchanges within the firm itself.

${ }^{5}$ See a review in Leunig, 'New answers'.

${ }^{6}$ On England, see Taylor, 'Concentration and specialization'; Farnie, English cotton industry; Lyons, 'Vertical integration'; Huberman, 'Vertical disintegration'. On France, see Sicsic, 'Establishment size'. On the United States, see Temin, 'Product quality'. On Germany, see Brown, 'Market organization'.
} 
coarse cloth than in those cotton mills specializing in fine goods. ${ }^{7}$ Trends across countries were also unclear: while vertical integration decreased progressively in England and France, in the United States and Spain it gained momentum over the course of the nineteenth century.

Within this international panorama, there is a highly interesting phenomenon: the dramatic transition of the Spanish cotton spinning and weaving industry in practically two decades (from 1840 to 1860) from a market-based system of business relations to a system of vertically integrated firms where intermediate yarn markets were replaced by internalization. However, at the same time, other phases of cotton production and trade remained vertically specialized: Barcelona cotton brokers and merchant-houses organized the supply of raw cotton; ${ }^{8}$ cottonfinishing firms were typically vertically specialized; and merchant-houses, agents, and independent travellers were responsible for the marketing of finished cloth. ${ }^{9}$

This article investigates vertical integration of cotton spinning and weaving firms in Spain in the mid-nineteenth century. The evidence indicates that vertical integration in the mid-nineteenth century was more closely related to the presence of asset specificity in intermediate yarn markets than to other factors. ${ }^{10}$ In other markets, like those of raw cotton, and semi-finished (grey) and finished cloth, where asset specificity problems appear to be less important, vertically disintegrated firms were more common.

Although this article focuses on the Spanish cotton industry, it may have much broader significance, since several of its arguments can serve to qualify the debate surrounding the role of vertical integration in the development of the cotton industry. The evidence collected in this article shows that the structure of intermediate markets could account for vertical integration. Consequently, regions with large markets for intermediate inputs and low concentration ratios, like Lancashire, would not need to have vertically integrated firms to develop their cotton industry efficiently. On the other hand, for regions where the extent of intermediate markets was limited and concentration ratios were high, vertical integration was the best option. This article also shows the weak relation between vertical integration and international competitiveness. Despite the preponderance of vertically integrated firms in cotton spinning and weaving, the Spanish cotton industry had a limited presence in international markets and maintained its domestic market, thanks to heavy tariff protection. ${ }^{11}$

As in many European countries, the development of the cotton industry was central to early industrial development in Spain during the nineteenth century. This industry was the single largest employer of manufacturing labour. It was also the first to import steam power technology and factory-based production from

\footnotetext{
${ }^{7}$ Huberman, 'Vertical disintegration'.

${ }^{8}$ Castañeda and Tafunell, 'Mercado mayorista'.

${ }^{9}$ Prat and Soler, 'Formación de redes comerciales'.

${ }^{10}$ The concept of asset specificity refers to the extent to which a particular investment might be used for alternative purposes.

${ }^{11}$ On the lower productivity of the Spanish cotton industry, see Rosés, 'Competitividad internacional', for the mid-nineteenth century, and Clark, 'Why isn't the whole world developed?', for the early twentieth century.
} 
abroad. ${ }^{12}$ Moreover, many cotton textile mills were among the largest Spanish manufacturing establishments. ${ }^{13}$ Although during the early industrialization period the cotton industry's rate of growth outstripped all other Spanish industries, its impact on overall growth rates was relatively limited. By 1860, cotton textiles' share in Spanish GDP was only between 1 and 2 per cent. ${ }^{14}$

The history of the Spanish cotton industry mainly concerns Catalonia. ${ }^{15}$ Textiles were well established in the region and Barcelona had been an important urban textile centre since the thirteenth century. However, it was during the eighteenth century, and especially after the 1780 s, that cotton textiles became an increasingly important component of the Catalan economy. ${ }^{16}$ The concentration of textile producers in Catalonia magnified the impact on the regional economy. Because of the geographic concentration of textile production, Catalonia industrialized more rapidly than the rest of the country. Moreover, Catalonia was the largest cotton textile producer in the Mediterranean basin, although this industry was tiny when compared with the British or New England cotton industries. By the 1850s, Catalan textile producers wove about one-seventeenth of the cloth woven in Britain and one-sixth of that produced in New England. ${ }^{17}$ It should be noted that the disparities in the quality of cotton cloth between these countries were as notable as the differences in amount of production. In general, Catalan cotton mills produced cloth somewhere between the coarser production of the New England mills and the finer quality of the Lancashire cotton mills. ${ }^{18}$

The early development of cotton textiles in Catalonia was gradual and was marked as much by continuity as by change. Nevertheless, transformation was not without its discontinuities, and the cotton industry in Catalonia experienced three successive phases: 1736-1780s; 1780s-1833; and 1833-61.

\section{The Early Period (1736-1780s) ${ }^{19}$}

Imitating several of the economic policies of the British and French governments, measures to encourage manufacturing expansion and economic development were introduced in Spain by the new Bourbon dynasty. ${ }^{20}$ An initial ban on the import of Asian cotton textiles was implemented in 1717 and was further extended in 1728 to European imitations. However, the legislation allowed the introduction of foreign cotton yarn. These measures provided an initial motivation for the development of cotton textiles in Catalonia; thus a first generation of enterprises dedicated to weaving and printing cotton was established in Barcelona after 1736. Nascent manufacturers sought to influence trade policy. Their lobbying had a

\footnotetext{
${ }^{12}$ Nadal, Fracaso, p. 195.

${ }^{13}$ The data collected in Giménez Guited, Guia fabril, shows that the cotton industry concentrated more than $60 \%$ of labour in manufacturing establishments with 50 or more workers.

${ }^{14}$ Rosés, 'Industrialización regional', pp. 64-72.

${ }^{15}$ According to Gimenez Guited, Guia fabril, p. 209, it produced about $75 \%$ of Spanish cotton textiles.

${ }^{16}$ In 1860, cotton textiles employed about one-third of the Catalan industrial workforce and about one-tenth of its total workforce (Rosés, 'Industrialización regional').

${ }^{17}$ Rosés, 'Choice of technology', pp. 136-7.

${ }^{18}$ Ibid.

${ }^{19}$ There is ample literature on the history of the cotton industry in Catalonia during this period. See recent reviews in Sánchez, 'Crisis económica', and Thompson, 'Technological transfer'.

${ }^{20}$ On these first developments, see Thompson, Distinctive industrialisation, pp. 67-72.
} 
long-standing impact on the measures concerning cotton textiles, and for most of the eighteenth and nineteenth centuries, cotton textile producers enjoyed strong protection. Nevertheless, this new industry benefited not only from government initiatives and protection, but also from the relative abundance of merchants, artisans, and machine-makers in Barcelona, as well as the fact that textile production was an ancient tradition of the region.

The following decades witnessed a considerable growth in cotton printing production in Barcelona. At the industry's peak in 1786, this city was the most important location in Europe for cotton printing, with 113 calico concerns. ${ }^{21}$ Catalan calicoes were sold on the protected domestic markets and to Spanish colonies in America. ${ }^{22}$ Simultaneously, there were also important improvements in the rate of technological innovation. By the mid-eighteenth century, Catalan manufacturers were pioneers among continental cotton industries in the adoption of innovations like indigo printing (1746) and engraved copper plates for printing $(1770) .^{23}$

\section{The Intermediate Period (1780s-1833) ${ }^{24}$}

The incorporation of the spinning process into the Catalan cotton industry characterized the second period of its development. As all cotton yarn was imported (mainly from Malta) for most of the eighteenth century, cotton spinning was of little importance in Catalonia. For example, the share of cotton yarn produced locally in 1784 was only 22 per cent, with the remaining 78 per cent being imported from Malta (43 per cent) and other Mediterranean ports. In 1784, two French machine-makers arrived in Barcelona, bringing with them the technology of the spinning jenny. The adoption of the spinning jenny by local manufacturers was immediate. ${ }^{25} \mathrm{~A}$ few years later, in 1792, an English engineer introduced an improved Highs jenny of 78 spindles (instead of the common 40 spindles) and a new card machine. The Arkwright water frame reached Catalonia soon after the Highs jenny. ${ }^{26}$ Over the next few years, local machine-makers were not only able to produce copies of the original spinning jenny but also developed a large jenny with more spindles (up to 120), called the 'bergadana' ${ }^{27}$ By the end of the century (1796), there were reported to be 250 bergadanas in operation. ${ }^{28}$

Successive wars and political disruptions were obstacles to the industry's progress during the first quarter of the nineteenth century. However, local production of cotton yarn and cloth was boosted by the bans on foreign imports of cotton yarn in 1802 and the introduction of mule-jennies from France in 1806. As had happened previously with the spinning jenny and the water frame, these wooden mule-jennies, powered by water wheels or horses, were rapidly copied by

\footnotetext{
${ }^{21}$ Thompson, 'Technological transfer'.

${ }^{22}$ A long-running debate surrounds the role played by the colonial and home markets in the development of the Catalan cotton industry. On this subject, see the review of the literature in Delgado, 'Mercado interno'.

${ }^{23}$ Thompson, 'Technological transfer'.

${ }^{24}$ On this period, see Sánchez, 'Era de la manufactura algodonera'; idem, 'Indianeria catalana'; idem, 'Crisis económica'; Thompson, Distinctive industrialisation; idem, 'Technological transfer'.

${ }^{25}$ Sánchez, 'Crisis económica', pp. 495-6.

${ }^{26}$ Thompson, Distinctive industrialisation, pp. 249-54.

${ }^{27}$ Ferrer Vidal, Conferencias, p. 101

${ }^{28}$ Sánchez, 'Crisis económica', p. 494.
} 
local machine-makers. ${ }^{29}$ In the following years, three major developments affected cotton spinning. Several new cotton mills with wooden mule-jennies powered by horses were established in Barcelona and the seaside district of Maresme. In the inland district of Bages, which had abundant water resources, water-frame spinning mills flourished. ${ }^{30}$ Simultaneously, hand spinning production shifted to areas in the north of Catalonia, an area with earlier manufacturing traditions and a good supply of cheap domestic labour. ${ }^{31}$ Following the spread of cotton spinning away from Barcelona, handloom weavers proliferated throughout Catalonia. ${ }^{32}$

Unlike cotton spinning and weaving, the cotton printing industry remained mainly located in Barcelona. ${ }^{33}$ Since the 1790s, calico concerns had experienced severe problems of overproduction, caused by the successive wars with England and France. In addition to these difficulties, the industry was also suffering from a structural crisis. Several forces were now working against centralized manufacture, which had predominated during the previous period. The large calico concerns gradually abandoned the production of yarn and cloth and concentrated on printing. Moreover, many of them disappeared during these years of turmoil, while new small-scale producers gained importance. ${ }^{34}$ Probably as a consequence of the combination of wartime and structural crises, the technological progress of the industry was extremely slow and few establishments adopted the new British and French machinery. ${ }^{35}$

\section{The Revolutionary Period (1833-1861) ${ }^{36}$}

The three decades preceding the 'cotton famine' witnessed dramatic changes, which affected all aspects of cotton production in Catalonia simultaneously. The rate of technological change accelerated dramatically with the arrival of new machinery from England. The average quality of local production also improved significantly. Finally, inland locations of the industry struggled, while coastal sites gained importance.

The first steam-powered mill appeared in 1833 when the company Bonaplata, Vilaregut, Rull \& Cía. began to produce cloth made on power looms in Barcelona. Throughout the 1830 s, steam power spread slowly in the Catalan cotton industry. In 1841, steam was clearly the least important source of power: of 2,014 horsepower (HP) employed in the Catalan mills in that year, only $289 \mathrm{HP}$, or 14 per cent, was obtained from steam. ${ }^{37}$ The pace of technological change accelerated in the 1840s with the end of the Civil War in 1840 and the removal of British restrictions on machinery exports. By 1850, the total HP employed in the industry

\footnotetext{
${ }^{29}$ Sánchez, 'Era de la manufactura algodonera', p. 83; Thompson, Distinctive industrialisation, pp. $263-4$.

${ }^{30}$ Thompson, Distinctive industrialisation, p. 261.

${ }^{31}$ Gutiérrez, Impugnación; Sánchez, 'Era de la manufactura algodonera'; Thompson, Distinctive industrialisation; García Balañà, Fabricació de la fàbrica.

${ }^{32}$ Sánchez, 'Era de la manufactura algodonera'; García Balañà, Fabricació de la fàbrica.

${ }_{33}$ Thompson, Distinctive industrialisation.

${ }^{34}$ Thompson (Distinctive industrialisation, pp. 268-301) offers a detailed account of the crisis of the large calico printing concerns.

${ }^{35}$ On the mechanization of calico printing, see Nadal and Tafunell, Sant Marti de Provençals, and Thompson, 'Technological transfer'.

${ }^{36}$ See a review of the literature on this period in Nadal, 'Indústria cotonera'.

${ }^{37}$ Sayró, Industria algodonera, and Madoz, Diccionario, vol. III, pp. 459-78.
} 
had increased to 3,755 and the proportion attributable to steam had soared to about 60 per cent. ${ }^{38}$ Eleven years later (1861), the total HP employed in the industry had increased to 5,800 and the proportion attributable to steam had risen to 67 per cent. $^{39}$

In Catalonia, technological progress in cotton spinning went hand in hand with the spread of steam power. Thus, from 1841 to 1850 , the number of hand-spindles declined dramatically from 725,787 to 180,058 , whereas the number of mechanical spindles grew from 316,320 to 524,178 . $^{40}$ Simultaneously, new iron mulejennies and throstles replaced the old wooden mule-jennies and water frames. By 1861 , the demise of hand spinning was complete, since practically all cotton yarn was produced with modern steam- or water-powered machinery. ${ }^{41}$ Moreover, new self-acting mules displaced mule-jennies from factories.

Technological change was slower in weaving than in spinning. The persistence of handloom weaving can be explained partly by technological reasons. Although the first profitable power-looms dated back to 1813, they were best suited to weaving coarse cloth. In the 1840 s and 1850 s, the adoption of high-pressure steam engines and the subsequent decrease in power costs extended the range of cloth types that could be produced efficiently with power-looms. ${ }^{42}$ This signified the progressive retreat of handloom weaving, which survived in the fancy segments of the market. It is also important to note that power-looms required high-strength yarn which was more economically produced with throstles or self-acting mules. In Catalonia, the first power-looms were introduced in $1828 .{ }^{43}$ In 1841 , however, the balance between handlooms and power-looms was still clearly favourable to hand machinery. ${ }^{44}$ In effect, for each power-loom in use, there were more than 100 handlooms. Ten years later (1850), the number of power-looms had increased 25-fold, while the number of handlooms remained roughly the same. ${ }^{45}$ The demise of handloom weaving was apparent in 1861 ; by this time, the number of handlooms had halved in comparison to 1850 figures, while the number of power-looms had multiplied by $1.7 .{ }^{46}$ Of the total cotton cloth woven in that year in Catalonia, only about one-fifth was made by hand-weavers. ${ }^{47}$

Technological advances also modified cotton-finishing processes drastically. In printing, manual processes using wooden blocks and copper plates were being replaced by engraved copper rollers by the mid-1780s. This new machinery dramatically increased the speed of printing and labour productivity. However, as was the case with weaving, block prints still had to be used in finishing patterns on fine goods after cylinders had printed most of the design. In Catalonia, techno-

\footnotetext{
${ }^{38}$ Arxiu del Foment del Treball de Catalunya (hereafter AFTC), Barcelona, fons Junta de Fábricas de Cataluña, Censo de fabricas de 1850.

${ }^{39}$ Comisión Especial Arancelaria, Información, vol. IV, pp. 38, 57.

${ }^{40}$ The first figure is from Sayró, Industria algodonera, and the second from Junta de Fábricas de Cataluña, Censo de fabricas de 1850, Arxiu del Foment del Treball Nacional, Barcelona.

${ }^{41}$ Giménez Guited, Guia fabril.

${ }^{42}$ See von Tunzelmann, Steam power, ch. 7. In contrast, Farnie, English cotton industry, pp. 277, 281-2, and Lyons, 'Powerloom profitability', pp. 398-400, stress the importance of the development of the Blackburn plain loom in 1841 .

${ }^{43}$ Ferrer Vidal, Conferencias.

${ }^{44}$ Sayró, Industria algodonera; Madoz, Diccionario, vol. III, pp. 459-78.

${ }^{45}$ AFTC, fons Junta de Fábricas de Cataluña, Censo de fabricas de 1850.

${ }^{46}$ Giménez Guited, Guía fabril, p. 209.

${ }^{47}$ See app.
} 
logical progress was exceptionally rapid in cotton printing during the 1840 s and 1850 s. In 1835, only four cylinder printing machines had been installed in Catalonia, but by 1850 the number of active machines had soared to 41, reaching 65 in 1861. The spread of the perrotine was even more impressive. This machine arrived from France only six years after its invention in 1840, and by 1861 there were 43 in use. ${ }^{48}$

Until the 1830s, Catalan cotton textile production was concentrated in the low grades of yarn (below 20 count) due to the unskilled workforce and the use of jennies and water frames. The spread of new machinery during the 1840 s and 1850 s went hand in hand with an increase in the quality of local production, since the average count increased to 30 count from about 15 count. More specifically, in the late $1850 \mathrm{~s}$, more than three-quarters of its production was in medium counts (20-40 count). At the same time, production of the finest quality was minimal (on average, less than the 2 per cent of the total in the 1850s). ${ }^{49}$

It should be noted that further changes in the location of the industry occurred during this period, as a consequence of the spread of steam power among cotton industrialists. More specifically, coastal locations, particularly Barcelona, gained in importance, while inland locations - even those well endowed with water-lost a significant part of their importance. ${ }^{50}$ In spite of these changes, cotton production remained relatively well distributed through Catalonia in comparison to Lancashire. For example, the distance between Barcelona and the capital of the second most important cotton district, Igualada (Anoia), was about 40 miles by road. More significantly, the most important location of cotton spinning and weaving in Catalonia, Barcelona, only accounted for about 40 per cent of total production (table 1, figure 1).

\section{II}

The eighteenth-century calico printing industry was based on medium-large and centralized production units, although several managerial structures, from capitalistic firms to artisans' shops, were to be found. The typical unit of production consisted of several work-teams with several masters, artisans, apprentices, and labourers. ${ }^{51}$ It was also integrated backward into cotton weaving and forward into marketing. The forward integration into marketing of calico producers was facilitated by the fact that many partners of the calico printing concerns were merchants. To distribute their products outside Catalonia, manufacturers organized a network of agents who were in charge of looking for buyers and received the fabrics on credit. For this reason, a considerable part of the capital of the calico concerns was commonly devoted to financing these marketing networks. However,

\footnotetext{
${ }^{48}$ Nadal, 'Indústria cotonera', pp. 34-7; Nadal and Tafunell, Sant Martí de Provençals, pp. 39-50.

49 This paragraph draws heavily on Rosés, 'Choice of technology', pp. 138-9.

${ }^{50}$ This trend was partly reversed after the 'cotton famine', when new water mills proliferated on the banks of the rivers Ter and Llobregat (Nadal, 'Indústria cotonera', pp. 48-64). This reversal of the normal dialectic of progression from water to steam was an exceptional characteristic of the Catalan cotton industry.

${ }^{51}$ Grau and López, 'Empresari'; Thompson, Distinctive industrialisation; Sánchez, 'Era de la manufactura algodonera'.
} 
Table 1. The share (\%) of the different districts in cotton textiles production, 1850 and 1861

\begin{tabular}{|c|c|c|c|c|}
\hline \multirow[b]{2}{*}{ Districts } & \multicolumn{2}{|c|}{ Spinning } & \multicolumn{2}{|c|}{ Weaving } \\
\hline & 1850 & 1861 & 1850 & 1861 \\
\hline Anoia & 15.41 & 10.20 & 5.98 & 5.66 \\
\hline Bages & 10.78 & 13.79 & 9.63 & 11.36 \\
\hline Barcelona & 43.48 & 34.81 & 38.69 & 42.84 \\
\hline Garraf & 3.34 & 7.59 & 4.07 & 9.57 \\
\hline Girona & 2.76 & 2.71 & 4.27 & 2.91 \\
\hline Maresme & 8.47 & 7.44 & 12.93 & 11.66 \\
\hline North & 8.19 & 11.56 & 5.89 & 4.84 \\
\hline South & 4.87 & 8.46 & 12.89 & 3.54 \\
\hline Vallès & 2.70 & 3.43 & 5.66 & 7.62 \\
\hline
\end{tabular}

Notes: The share of each district is computed as the ratio between the estimated production in tons of yarn or cloth per year of a given district and the total estimated production in tons of yarn or cloth per year of Catalonia. The actual counties (comarques) of Alt Penedés, Anoia, Baix Llobregat, and Conca de Barberà formed the cotton district of Anoia; the county of Bages formed the cotton district of Bages; the county of Barcelonés formed the cotton district of Barcelona; the county of Garraf formed the cotton district of Garraf; the counties of Gironés, la Selva, Garrotxa, and Pla de l'Estany formed the cotton district of Girona; the county of Maresme formed the district of Maresme; the counties of Cerdanya, Solsonés, Berguedà, and Osona formed the North cotton district; the counties of Alt Camp, Baix Camp, and Tarragones formed the South cotton district; and, finally, the counties of Vallès Occidental and Vallès Oriental formed the cotton district of Vallès.

Sources: For 1850: Junta de Fabricas de Cataluña, Censo de fábricas de 1850, Arxiu del Foment del Treball Nacional, Barcelona. For 1861: Giménez Guited, Guia fabril, pp. 24-65, 90-8, 111-12, 152-68. For an estimation of production and coverage of the sample, see app.

particularly in overseas trade, cotton concerns sometimes employed alternative channels of distribution, such as cloth wholesalers, independent travellers, and specialized merchant-houses. ${ }^{52}$

A movement towards specialization began in the early 1790s, with the spread of cotton spinning and weaving away from Barcelona. ${ }^{53}$ The precise relation between the interrelated sources of entrepreneurship and capital and the product strategies and the scale of firms during this period is difficult to determine. ${ }^{54}$ It was clear, however, that a complex interaction between different cotton textile producers and merchants was replicated throughout Catalonia. For example, the medium-sized textile producers frequently rented space, and sometimes power, to the largest producers. Although business organization was very far from impersonal atomistic competition, there was no question of a single producer or group exerting overwhelming dominance.

To be more precise, in the hand-spinning districts of the north of Catalonia, yarn production was organized as in the typical cottage industry, but also in artisans' shops. ${ }^{55}$ In a cottage industry, the subcontractor provided raw materials and

52 Thompson, Distinctive industrialisation, pp. 87-8.

53 Sánchez, 'Era de la manufactura algodonera', pp. 93-9.

${ }^{54}$ Recent detailed accounts of the cotton industry structure are available in Solà Parera, Aigua; García Balañá, Fabricació de la fàbrica; and Ferrer Alós, 'Bergadanas'. It is interesting to note the close parallels with Lancashire during the period. See Rose, Firms, pp. 58-98, on the situation in Lancashire.

${ }^{55}$ See Ferrer Alós, 'Bergadanas', p. 345. 


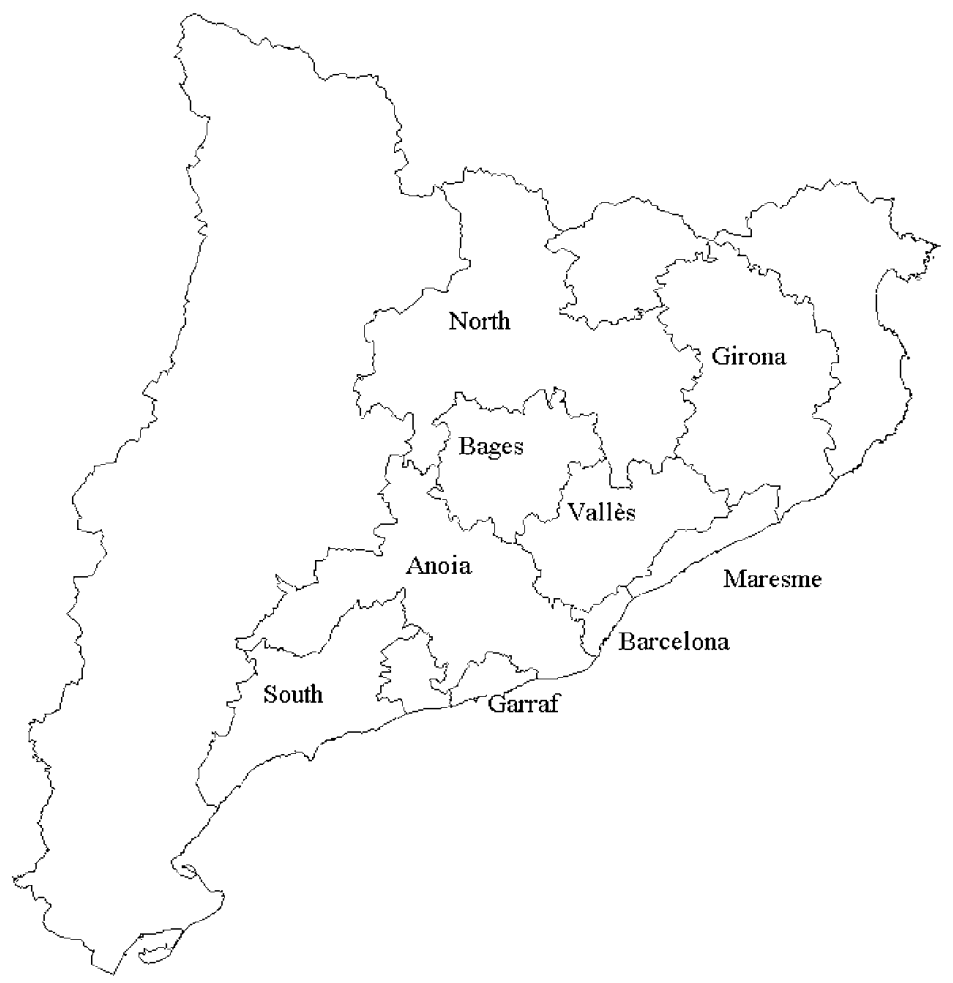

Figure 1. The cotton districts of Catalonia, c.1850

Notes: See tab. 1.

Source: Author's elaboration.

semi-finished goods to a producer (usually female) who used their own tools and also played, at least to some extent, a supervisory role with regard to the final product. In small artisans' shops, mainly located in Berga, men and women worked together. Women were involved in yarn production, while men took care of cloth production and controlled the overall process; there was, therefore, a certain vertical integration between cotton spinning and weaving.

Handloom weaving in districts like Anoia, Osona, and Bagés provides a model example of independent artisan production. In handloom weaving workshops, several artisans, with a few assistants, who were sometimes young members of the family, ran a small production unit with limited division of labour. In contrast, handloom putting-out networks predominated in other districts. The organization of these domestic networks was very similar to that of cotton spinning. Consequently, although domestic producers used their own looms, the sub-contractor provided yarn and played a supervisory role with regard to the final product. ${ }^{56}$

56 Ibid. 
During the same period, the new cotton spinning mills in Barcelona and the districts of Maresme and Bages became specialized and did not integrate forward into cotton weaving. Similarly, printing concerns, mainly located in Barcelona, abandoned backward integration into cotton weaving and, hence, used the cloth made by independent handloom weavers. Therefore, spinning mills and printing concerns frequently relied on external contracts with independent handloom weavers.

The technological advances of the 1840s and 1850s were accompanied by the proliferation of two different types of mills, although other types of business organizations (like workshops and putting-out networks) survived. In coastal locations the town mills predominated, whereas river mills held the upper hand in inland locations. ${ }^{57}$ The typical town cotton mill used steam power and self-acting mules (and sometimes power-looms), and produced yarn and/or cloth of medium quality. The typical river mill, on the other hand, was water-driven and employed throstles and self-acting mules (and also sometimes power-looms) to produce coarse yarn and heavy cloth. These different patterns of specialization were the result of two major factors: the cost structure of the different types of yarn and cloth and the characteristics of the labour force. ${ }^{58}$ River mills saved on coal but were more capital-intensive, while town mills saved on capital but were more labour-intensive. Furthermore, town mills tended to employ more skilled labour than river mills, whose workforce consisted mainly of young women. This led to two types of shop-floor organization: teams and internal subcontracting predominated in town mills, whereas foremanship practices were much more common in river mills.

Other dramatic changes affected the organization of the cotton industry in Catalonia during the $1840 \mathrm{~s}$ and $1850 \mathrm{~s}$. Vertical integration of cotton spinning and weaving was not common before the 1840 s, but increased dramatically in the following years (see table 2) ${ }^{59}$ According to the industrial survey for 1850 , vertical integration was quite widespread in the field of cotton spinning: 229 firms with 9,389 spinners operated exclusively in cotton spinning, and 85 firms with 4,235 spinners had integrated vertically into cotton spinning and weaving. ${ }^{60}$ These firms also employed about half of the power installed and more than one-third of the mechanical spindles. Particularly relevant was their share of self-acting mules, since they employed 68 per cent of the total of this modern spinning machinery. In cotton weaving, the share of vertically integrated firms was smaller than in cotton spinning, due to the abundance of very small firms, all hand-powered, in this industry. However, as in cotton spinning, vertically integrated firms used the most modern machinery. For example, more than 83 per cent of power-looms were installed in vertically integrated firms. For that reason, more than 40 per cent of cloth production was in the hands of these firms, even though they employed only 15 per cent of weavers.

\footnotetext{
${ }^{57}$ Steam-powered cotton mills predominated in the districts of Barcelona, Garraf, Maresme, South, and Vallés, whereas water-driven cotton mills were common in the districts of Anoia, Bages, Girona, and North.

${ }^{58}$ The cost structure of different cotton products according to quality in Catalonia is available in Rosés, 'Choice of technology', pp. 150-3.

${ }^{59}$ The first vertically integrated cotton spinning and weaving firms had appeared in the last years of the eighteenth century. See Sánchez, 'Era de la manufactura algodonera'.

${ }^{60}$ See app. for sources.
} 
Table 2. The diffusion of vertical integration in cotton spinning and weaving, 1850 and 1861

\begin{tabular}{|c|c|c|c|c|c|c|c|c|}
\hline & \multicolumn{4}{|c|}{1850} & \multicolumn{4}{|c|}{1861} \\
\hline & Firms & $\%$ & Production & $\%$ & Firms & $\%$ & Production & $\%$ \\
\hline \multicolumn{9}{|c|}{ Panel A: spinning } \\
\hline Specialized & 229 & 72.93 & 7,654 & 63.99 & 149 & 58.20 & 6,740 & 39.06 \\
\hline Integrated & 85 & 27.07 & 4,308 & 36.01 & 107 & 41.80 & 10,518 & 60.94 \\
\hline Total & 314 & 100.00 & 11,962 & 100.00 & 256 & 100.00 & 17,258 & 100.00 \\
\hline \multicolumn{9}{|c|}{ Panel B: weaving } \\
\hline Specialized & 891 & 91.29 & 5,779 & 55.69 & 411 & 79.34 & 5,039 & 33.01 \\
\hline Integrated & 85 & 8.71 & 4,598 & 44.31 & 107 & 20.66 & 10,225 & 66.99 \\
\hline Total & 976 & 100.00 & 10,377 & 100.00 & 518 & 100.00 & 15,264 & 100.00 \\
\hline
\end{tabular}

Notes: Some rounding of numbers. Firms with fewer than 10 workers have been excluded from the table. Production is expressed in tons of yarn (spinning panel) and cloth (weaving panel). Specialized spinning firms are spinning firms without a weaving section. Specialized weaving firms are weaving firms without a spinning section. Integrated firms are firms with both spinning and weaving sections.

Sources: See tab. 1.

In the 1850 s, vertically integrated cotton mills continued their expansion, capturing the market for medium-coarse cloth. However, well before the 1860s, some horizontal spinning mills and domestic hand-weavers survived by producing for more fashion-oriented segments of the market. ${ }^{61}$ By 1861, vertically integrated firms employed more than 60 per cent of spindles and more than 80 per cent of power-looms, and produced 67 per cent of cotton cloth. ${ }^{62}$ Moreover, in 11 years, the number of vertically integrated firms had increased by 25 per cent, while the number of specialized firms decreased by about 35 per cent in cotton spinning and more than halved in weaving.

In comparison with England and France, vertical integration was much more important in Catalonia. ${ }^{63}$ English vertically integrated cotton mills employed 52.9 per cent of workers, 63.9 per cent of power-looms, and 41.8 per cent of mechanical spindles in $1861 .{ }^{64}$ French vertically integrated cotton mills employed only 3 per cent of the cotton textiles workforce.$^{65}$ In sharp contrast, Catalonian vertically integrated mills employed 65.8 per cent of workers, 80.2 per cent of power-looms, and 55.2 per cent of spindles.

The integration of cotton spinning and weaving with cotton printing was a comparative rarity. In 1850, only four of 57 printing firms also vertically integrated cotton weaving. These vertically integrated firms employed 9 per cent of the workers and 14 per cent of the steam power used in the cotton printing industry. ${ }^{66}$ As with the integration of cotton spinning and weaving, integration into cotton printing progressed during the $1850 \mathrm{~s}$, although it remained relatively scarce in comparison with cotton spinning and weaving. By 1861, seven of 41 firms

\footnotetext{
${ }^{61}$ Comisión Especial Arancelaria, Información.

${ }^{62}$ Gimenez Guited, Guia fabril. For estimation of production, see app.

${ }^{63}$ To compare Catalonia and England correctly, it is necessary to convert the Catalan data to the British standards. The British sources do not report all labour because, for example, handloom weavers were not included. For this reason, only steam-powered and water-driven factories with more than 10 workers were considered. Gatrell, 'Labour', offers a detailed description of British sources.

${ }^{64}$ Farnie, English cotton industry, p. 317.

${ }^{65}$ Sicsic, 'Establishment size', p. 459.

${ }^{66}$ AFTC, fons Junta de Fábricas de Cataluña, Censo de fabricas de 1850.
} 
Table 3. The size distribution of cotton spinning and weaving firms, 1850 and 1861

\begin{tabular}{|c|c|c|c|c|c|c|c|}
\hline & \multirow[b]{2}{*}{$\begin{array}{c}\text { Firm size } \\
\text { (Metric tonnes per year) }\end{array}$} & \multicolumn{3}{|c|}{ Spinning } & \multicolumn{3}{|c|}{ Weaving } \\
\hline & & $\underset{<50}{\text { Small }}$ & $\begin{array}{c}\text { Medium } \\
50-100\end{array}$ & $\begin{array}{l}\text { Large } \\
>100\end{array}$ & $\underset{<50}{\text { Small }}$ & $\begin{array}{c}\text { Medium } \\
50-100\end{array}$ & $\begin{array}{l}\text { Large } \\
>100\end{array}$ \\
\hline \multicolumn{8}{|l|}{ Panel A: 1850} \\
\hline \multirow{2}{*}{ Specialized } & Firms & 173 & 48 & 8 & 882 & 7 & 2 \\
\hline & Production & 3,399 & 3,155 & 1,100 & 4,943 & 444 & 392 \\
\hline \multirow[t]{2}{*}{ Integrated } & Firms & 56 & 16 & 13 & 59 & 14 & 12 \\
\hline & Production & 876 & 1,140 & 2,292 & 493 & 1,041 & 3,064 \\
\hline \multirow[t]{2}{*}{ Total } & Firms & 229 & 64 & 21 & 941 & 21 & 14 \\
\hline & Production & 4,274 & 4,295 & 3,392 & 5,436 & 1,485 & 3,456 \\
\hline \multicolumn{8}{|l|}{ Panel B: 1861} \\
\hline \multirow[t]{2}{*}{ Specialized } & Firms & 103 & 40 & 6 & 393 & 8 & 10 \\
\hline & Production & 2,640 & 3,113 & 987 & 3,028 & 582 & 1,429 \\
\hline \multirow[t]{2}{*}{ Integrated } & Firms & 50 & 28 & 29 & 56 & 18 & 33 \\
\hline & Production & 1,266 & 2,276 & 6,976 & 803 & 1,302 & 8,120 \\
\hline \multirow[t]{2}{*}{ Total } & Firms & 153 & 68 & 35 & 449 & 26 & 43 \\
\hline & Production & 3,907 & 5,389 & 7,963 & 3,831 & 1,884 & 9,550 \\
\hline
\end{tabular}

Notes and sources: See tab. 1.

integrated the two consecutive phases and employed about 24 per cent of modern printing cylinders, but a lower proportion of the old machinery ${ }^{67}$

Vertically integrated firms predominated among the largest firms in both cotton spinning and weaving (see table 3 ). In cotton spinning in 1850, only one-third of the smallest firms (producing less of 50 tons of yarn per year) were integrated vertically, whereas this proportion grew to 62 per cent in the case of the largest firms (producing more than 100 tons of yarn per year). Similarly, in cotton weaving in 1850, only 6 per cent of the firms producing less than 50 tons of cloth per year were vertically integrated, whereas the figure grew to 86 per cent for firms producing more than 100 tons of cloth per year.

In the 11 years from 1850 to 1861 , the size of the average cotton spinning and weaving firm grew considerably. In cotton spinning, average production per firm rose from 38 tons of yarn per year in 1850 to 67 tons of yarn per year in 1861 . Similarly, in cotton weaving, average production per firm went up from 10.6 tons of cloth per year in 1850 to 29 tons of cloth per year in 1861. This growth in average production was mainly due to the increasing share of the largest firms in total production. However, the share of vertically integrated firms among the largest firms decreased slightly. Therefore, the number of very large vertically integrated firms grew mainly because the number of large firms also increased.

Previous accounts of the cotton industry tend to stress that specialized and integrated firms differed in both type of products and degree of specialization. Vertically integrated firms in England and the United States tend to produce coarser cloth, and hence coarser yarn, than specialized firms.$^{68}$ On the other hand, specialized English spinners typically focused their production on a narrow range of counts, while specialized weavers also concentrated in a relatively narrow range

\footnotetext{
${ }^{67}$ Giménez Guited, Guia fabril.

${ }^{68}$ Temin, 'Product quality'.
} 
Table 4. The relation between type of firm and cloth quality, 1860

\begin{tabular}{lccc}
\hline Type of firm & $\begin{array}{c}\text { Coarse cloth } \\
\text { (counts below 20) }\end{array}$ & $\begin{array}{c}\text { Medium cloth } \\
\text { (counts 20-60) }\end{array}$ & $\begin{array}{c}\text { Fine and fancy cloth } \\
\text { (counts 60+) }\end{array}$ \\
\hline Weaving & 2 & 2 & 14 \\
Printing & 2 & 12 & 6 \\
Spinning and weaving & 4 & 10 & 0 \\
Spinning, weaving, and printing & 2 & 9 & 1 \\
\hline
\end{tabular}

Notes: Some firms produced more than one quality of cloth. Coarse cloth: Curados, Cutíes, Driles, Empesas, and Percalinas bastas. Medium cloth: Brillantinas, Elefantes, Empesas finas, Guineas, Hamburgos, Indianas normales, Madepolan, Muselinas, Panas, Percalinas, Retores, Ruanesas, and Semi-retores. Fine cotton cloth and mixed fabrics: Batistas, Castores, Chalecos, Florentinas, Guatas, Indianas finas, Pañuelos, and Piqués.

Sources: The source of data on production is Orellana, Exposicion $;^{70}$ the classification of the quality of products is based on Ronquillo, Diccionario; and the classification of firms is based on Gimenez Guited, Guia fabril, pp. 24-65, 90-8, 111-12, 152-68.

of cloths. By contrast, English integrated firms producing for the domestic market tended to produce a wide variety of products. ${ }^{69}$

As table 4 shows, vertically integrated firms in Catalonia, regardless of whether they vertically integrated spinning and weaving or all three phases (spinning, weaving, and printing), tended to produce medium-coarse cloth. Specialized weaving firms, however, tended to produce fine and fancy cloth. Finally, cottonfinishing firms produced all types of cotton goods, since cloth quality depended on the weaving firms. Commonly, these cotton printing firms elaborated a reduced range of products and were sometimes subcontracted by cotton weaving firms.

As in Britain, vertically integrated cotton firms in Catalonia tended to produce a wider variety of products than specialized firms. ${ }^{71}$ Thus, weaving firms produced on average 1.4 different cloths (standard deviation of 0.79), printing firms an average of 1.8 different fabrics (standard deviation of 1.05), and vertically integrated firms an average of 3.5 different fabrics (standard deviation of 2.44). However, vertically integrated firms (larger than specialized firms) produced on average a larger quantity of each type of cloth than specialized firms. ${ }^{72}$ The series of cloth produced by specialized firms weighed on average 24 tons (standard deviation of 19) whereas these series in integrated firms weighed an average of 109.5 tons (standard deviation of 40). Consequently, vertically integrated firms produced their standardized products (coarser cloth) on a larger scale than the specialized firms which produced finer and fancy cloths. Fine and fancy cloths were produced in small batches (to order), and required a shorter series than the coarser fabrics. ${ }^{73}$

There were remarkable differences in the distribution of vertically integrated firms across cotton districts in Catalonia (see table 5), although this model of

\footnotetext{
${ }^{69}$ Brown, 'Market organization'.

70 This book collects data on cotton firms which showed their products in an exhibition to honour the Queen during her visit to Barcelona. The sample consisted of 54 firms (17 weaving firms, 14 printing firms, and 23 vertically integrated firms).

${ }^{71}$ Nadal ('Indústria cotonera', pp. 65-8) attributed this option to the small size of the Spanish home market.

${ }^{72}$ The average number of tons of cloth of each different series is obtained by dividing the total amount of cloth produced per firm in 1861 by the number of different cloths shown in the exhibition.

${ }^{73}$ The home market for high-quality cotton goods was relatively small, due to the relatively lower Spanish income and its unequal distribution (Prados de la Escosura, 'Producción y consumo', pp. 465-7). Moreover, Spanish firms were not competitive in international markets and foreign products (mainly from Britain and France) dominated a large part of this market (Rosés, 'Competitividad internacional'). Consequently, Spanish firms producing the finest goods were small.
} 
Table 5. District shares (\%) of vertically integrated firms, 1850 and 1861

\begin{tabular}{|c|c|c|c|c|}
\hline \multirow[b]{2}{*}{ Districts } & \multicolumn{2}{|c|}{ Spinning } & \multicolumn{2}{|c|}{ Weaving } \\
\hline & 1850 & 1861 & 1850 & 1861 \\
\hline Anoia & 11.23 & 56.09 & 28.70 & 67.01 \\
\hline Bages & 47.34 & 56.55 & 69.93 & 76.09 \\
\hline Barcelona & 31.81 & 66.40 & 40.84 & 62.56 \\
\hline Garraf & 100.00 & 100.00 & 100.00 & 99.78 \\
\hline Girona & 38.97 & 48.71 & 59.93 & 71.51 \\
\hline Maresme & 20.76 & 76.59 & 13.79 & 41.03 \\
\hline North & 35.67 & 26.49 & 13.77 & 57.80 \\
\hline South & 52.76 & 60.20 & 35.45 & 71.69 \\
\hline Vallès & 16.16 & 27.86 & 2.21 & 27.76 \\
\hline
\end{tabular}

Notes: The share of vertically integrated firms is computed as the ratio between the estimated production in tons of yarn or cloth per year of vertically integrated firms and the estimated production in tons of yarn or cloth per year of a given district.

Sources: See tab. 1.

business organization progressed rapidly between 1850 and 1861 in all districts (the only exception to this general rule was cotton spinning in the North district). However, there was no discernible pattern of vertical integration for river and town cotton mills. Thus, vertical integration predominated in certain districts with town mills, such as Garraf, while it was relatively scarce in others, like Maresme and Vallés. Similarly, vertical integration was dominant in districts with many river mills, such as Bages, but was less important in others, like the North. ${ }^{74}$ Moreover, the existence of vertical integration cannot be linked to the predominance of foremanship practices on the shop floor. For example, the largest Catalan cotton firm, the España Industrial, located in Barcelona, was vertically integrated and organized its workforce into work teams.

\section{III}

As the extensive literature makes clear, vertical integration is a complex phenomenon resulting from many causes which may act alone or interact. Moreover, as Joskow has recently noted, 'there is not and will never be one unified theory of vertical integration'. ${ }^{75}$ However, the transaction cost theory of the firm is the most widely employed framework for the study of these institutional arrangements. ${ }^{76}$

Coase was the first to argue that firms integrate to avoid the costs of market exchange. ${ }^{77}$ Modern transaction cost theory holds that these costs will be higher the fewer the number of parties in the market and the more specialized the assets involved in the transaction, known as asset specificity. When exchange implies

\footnotetext{
${ }^{74}$ Therefore there was no close connection between the predominance of foremanship practices and vertical integration, since many town mills, where work teams were more important, were also vertically integrated.

${ }^{75}$ Joskow, 'Vertical integration', p. 320.

${ }^{76}$ Two alternative frameworks are used for the analysis of vertical integration: the neoclassical theories of vertical integration and the property rights approach. A good review of the different approaches can be found in Joskow, 'Vertical integration'. See also Shelanski and Klein, 'Empirical research', and Klein, 'Make-or-buy decision', for the empirical literature.

${ }^{77}$ Coase, 'Nature'.
} 
sizeable investments in relationship-specific capital, an exchange relationship depending on repeat bargaining is unattractive. Investment in such assets exposes agents to a potential hazard, since the lack of alternative uses raises the scope for opportunistic behaviour between contracting parties. If conditions vary, trading partners may try to expropriate the rents accruing to the specific assets. This is the so-called 'hold-up' problem. ${ }^{78}$ Rents can be protected by means of vertical integration, where a merger eliminates any adversary interests, or by the use of contractual safeguards, such as formalized long-term contracts and reputation. ${ }^{79}$ As a rule, non-specific investment will result in market governance (subcontracting), while specific or idiosyncratic investment and recurrent transacting will result in firm governance (vertical integration). All in all, when a firm invests in assets with a high degree of asset specificity, it tends to integrate into the next phase in order to avoid opportunism in its transactions with other firms. Williamson identifies up to five different situations in which asset specificity is thought to arise: physical asset specificity, dedicated assets, site specificity, human asset specificity, and intangible assets. The first three are the most pertinent in the study of the vertical integration of cotton spinning and weaving. ${ }^{80}$

To analyse the issue of the determinants of the decision to vertically integrate cotton spinning and weaving, this section follows the standard empirical strategy of transaction cost literature. ${ }^{81}$ Vertical integration is seen as a function of a certain asset specificity property of the underlying transaction. Given that asset specificities (or transaction costs) are not directly observable (and difficult to measure), several of the typical proxies for asset specificity, such as market concentration, production capacity, and type of technology, are used.

Two alternative definitions of the dependent variable, vertical integration of cotton spinning and weaving production, are employed in this article, although the same set of independent variables is considered to explain them. The first treats vertical integration as a dummy variable, where a cotton firm is vertically integrated if it is in possession of machinery for both phases of production. The second approach treats vertical integration as a limited dependent variable, measured by the ratio of cloth production capacity to yarn production capacity in the case of cotton spinning and the inverse in the case of cotton weaving. A ratio of one is assumed to indicate self-sufficiency. In the case of cotton spinning, a ratio of less than one suggests market transaction to sell excess yarn (for example, if the value is zero, this indicates that the firm put all its yarn into market transactions). Similarly, in the case of cotton weaving, a ratio of less than one suggests market transactions to supplement the production of cloth.

Market concentration serves as a proxy for the potential of a small-numbers bargaining problem, since it suggests the amount of alternative suppliers (or buyers) that firms may turn to in the event of opportunistic behaviour by another

\footnotetext{
${ }^{78}$ Williamson, Markets; idem, Economic institutions; idem, Mechanisms of governance; Klein, Crawford, and Alchian , 'Vertical integration'; Grossman and Hart, 'Costs'.

${ }^{79}$ In the case of the early Spanish cotton industry, reputation matters little, since firms were commonly new and the survival rate was very low. Similarly, contracts were difficult to enforce because of Spanish law and the changing political situation.

${ }^{80}$ Williamson, Mechanisms of governance, p. 105.

${ }^{81}$ See Klein, 'Make-or-buy decision', for a detailed analysis of the strategies for empirical research in transaction cost economics.
} 
party. ${ }^{82}$ Thus, high concentration could be associated with situations where there is greater possibility of hold-up problems and a greater incentive to integrate vertically. In the case of high concentration ratios, dedicated assets and site specificity problems may appear. Dedicated assets problems arise when a supplier makes an investment that would not otherwise be made but for the expectation of selling a substantial amount to a particular buyer(s). If that relationship terminated suddenly, it would leave the supplier with significant excess of capacity. There is also a 'buyer' side analogy to the dedicated asset history as well. ${ }^{83} \mathrm{~A}$ buyer who relies on a single (or few) supplier(s) for a large volume of an input may find it difficult and costly to replace these supplies immediately if they are terminated prematurely. Consequently, it would be very risky to set up a cotton-spinning firm in a certain location if the firm had not found enough demand, and different buyers, for the quantity of yarn of a certain count (quality) that it was able to put onto the market. For this reason, it could be interesting for firms setting up in certain locations with few buyers of their yarn to integrate into the next phase instead of growing horizontally by acquiring more firms in the same phase. An analogous problem, but on the buyer side, arises with cotton weaving firms. If a cotton weaving firm enters a particular market with a small number of yarn producers, it could suffer from hold-up problems with its suppliers. On the other hand, site specificity arises when successive stages are located in close proximity to one another, reflecting previous decisions to minimize inventory and transport expenses. The Catalan cotton industry was relatively spread out over many districts (see table 5). More significantly, many mills were water-powered and were located in the countryside, relatively isolated from suppliers and/or buyers. Even many steam-powered mills were located in districts where the number of alternative suppliers and/or buyers was relatively small. Consequently, given that reallocation costs were high, it is likely that mills in districts with high concentration ratios tended to integrate vertically cotton spinning and weaving.

The decision to integrate and the extent of vertical integration are hypothesized to be a positive function of firm size, because the transaction-cost savings would be greater in larger firms compared to smaller firms (all else being equal). There are several reasons for this. Firstly, larger firms suffer more dedicated asset problems than smaller firms, because the costs of a supply (demand) disruption would be greater than for smaller firms. ${ }^{84}$ Secondly, if the frequency of transaction rises with firm size, a higher frequency of transactions will increase the gains arising from integration and may justify the costs of internal organization. ${ }^{85}$

\footnotetext{
${ }^{82}$ Ohanian ('Vertical integration') suggests this test for transaction cost theory. It should be noted, however, that the high market concentration indicator is also consistent with monopoly (monopsody) power explanations for vertical integration. Moreover, transaction-cost- and market-power-based theories of vertical integration are difficult to distinguish empirically, since each makes similar predictions (see MacDonald, 'Market exchange'). However, the objective of this paper is not to test the superiority of one theory over the other, but to present an explanation for vertical integration in the cotton industry. It is clear from the results that high buyer and seller concentration ratios were closely related with vertical integration. Therefore, I do not reject an alternative interpretation based on market power, although it seems less plausible within the Spanish historical context, given the behaviour of prices in cotton yarn, grey cloth, and printed cloth.

${ }^{83}$ Joskow, 'Contract duration'.

${ }^{84}$ Temin ('Product quality', p. 902) raises a similar point.

${ }^{85}$ In contrast, other authors hypothesize a negative relation between firm size and the probability of integration, due to managerial diseconomies of scale. For a full discussion of the managerial problems and advantages of vertical integration, see Williamson, Economic institutions, ch. 6.
} 
Thirdly, the presence of imperfections in capital markets can provide larger firms with an incentive for vertical integration. Vertical integration works as an internal capital market and, therefore, it represents the elimination of financial intermediaries. ${ }^{86}$ In other words, the absence of external financing can provide an incentive for firms to buy the next phase and to employ the money invested in circulating capital (that is, the money used for credit to customers) within the firm. In Spain, the small size of the market and its unstable character caused difficulties for financial institutions trying to develop an impersonal system of money lending. ${ }^{87}$ Thus, Catalan cotton firms used an important part of their resources to finance their own customers, since loans from banks and other financial intermediaries were scarce. It was not common for wholesalers or shops to pay in advance or amortize their debts over short periods. Similarly, small firms could not easily borrow money or discount bills of exchange in banks. For this reason, it was common for larger firms to finance smaller industrial firms. Consequently, for large cotton firms, it may have been a good idea to integrate backward (or forward), because they had already indirectly financed this phase, and to convert the circulating capital lent to other companies into fixed capital which was directly owned by the company.

Finally, a positive relation between modern machinery and vertical integration is hypothesized. Physical assets and dedicated assets specificity can account for this situation. Physical asset specificity problems arise when firms make investments in equipment and machinery with design characteristics specific to the transaction and, hence, lower values in alternative uses. Several technical characteristics of the machinery available in the cotton industry during the second third of the nineteenth century could generate this kind of problem. Firstly, the self-acting mule in cotton spinning and the power-loom in cotton weaving were only suitable for medium and coarse qualities. Secondly, as previously seen, they produced longer series than other types of machinery; consequently, they also incurred dedicated assets problems. The old technologies, mule-jennies and handlooms, were more efficient in the elaboration of fine cloth and mixed fabrics and could produce in small batches (to order) ${ }^{88}$ Thirdly, power-looms required very homogeneous high-strength yarn to avoid recurrent breakouts during the weaving process. Only self-acting mules and throstles were capable of producing the required amount of homogeneous high-strength yarn, since mule-jennies and hand-spindles were unable to do so. ${ }^{89}$ Power-loom weaving firms could not know ex ante this quality of the yarn. In effect, the frequency of breakdowns was the only available indicator of whether yarn met the strength requirements. Moreover, the marginal value of this high-strength yarn was nothing for handloom weavers, since they could employ all types of yarn without additional

\footnotetext{
${ }^{86}$ Williamson, Markets; Mowery, 'Finance'.

${ }^{87}$ Graell, Informació pública.

${ }^{88}$ Spanish contemporary technical handbooks refer to these problems with the self-acting mule and the advantages of maintaining the use of mule-jennies. See, for example, Arau, Tratado completo. However, the self-acting mule was more flexible than the throstle, as the latter efficiently produced only a very limited range of counts in larger series. See also von Tunzelmann, Steam power, and Lyons, 'Powerloom profitability', pp. 398-400.

${ }^{89}$ Von Tunzelmann, Steam power, and Lyons, 'Powerloom profitability'.
} 
costs. ${ }^{90}$ Consequently, theory predicts that firms employing self-acting mules or/and power-looms (modern machinery) tend to integrate vertically cotton spinning and weaving more frequently than firms employing mule-jennies or handlooms.

These arguments can be formalized into the following pair of equations:

$$
\begin{aligned}
& \text { Vertical integration (PROB =1) } \\
& \quad=\mathrm{F}(\text { concentration, size, modern machinery }) \text {, } \\
& \text { Cloth (yarn) production/yarn (cloth) production } \\
& \quad=\mathrm{F} \text { (concentration, size, modern machinery). }
\end{aligned}
$$

Equation (1) can be estimated by a logit and logistic regression (the dependent variable takes the value 1 if vertical integration is positive). ${ }^{91}$ In equation (2), because the dependent variable is limited between 0 (market transaction) and 1 (self-sufficiency), this model should be estimated using a Tobit regression. ${ }^{92}$

Table 6 presents a variety of estimation results that are broadly consistent with each other, suggesting that the results are robust to regression specification. The explanatory variables worked reasonably well. All of the coefficients are of the expected sign and significant on nearly all occasions. More importantly, the odds ratios of the concentration variable are very high (above four). ${ }^{94}$ However, some differences between the different estimations are noteworthy. In particular, the different specifications provide a better explanation of vertical integration in cotton weaving than in the spinning sector. This is mainly due to the high significance of the variable 'machinery' in cotton weaving, indicating that physical asset specificity was very important in the case of the adoption of power-looms. It is likely,

\footnotetext{
${ }^{90}$ This problem could have been solved if Catalan weaving firms had established long-term contracts with their yarn suppliers, or a system of reputation based on trademarks. However, during this period, the firms survived for short periods (typically five years or less) and contracts were hard to enforce, given the well-known inefficiency of the Spanish legal system. Moreover, Spanish patent law did not protect trademarks and quality improvements from imitations.

${ }^{91}$ Logistic is identical to logit regression, but it calculates odds ratios instead of coefficients (sometimes called logits in this type of regression). The logit can be easily converted into an odds ratio simply by using the exponential function (raising the natural $\log$ e to the $b_{1}$ power). Note that an odds ratio above 1.0 means that the odds of getting ' 1 ' on a dependent dichotomous variable are greater for the given category.

${ }^{92}$ However, with these different methods of regression, one cannot control the unobservable heterogeneity (González-Díaz, Arruñada, and Fernández, 'Causes of subcontracting'). If one assumes that this unobservable heterogeneity is a firm-specific component, this can be addressed by using panel data techniques, given that observations are available for two different periods (1850 and 1861). Following the standard procedure described in Greene, Econometric analysis, pp. 479-80, one has two alternative models: fixed and random effects. If individual effects and regressors are correlated, the choice should be a fixed-effects model. On the other hand, if regressors and individual effects are orthogonal, one should employ the random-effects model. The Hausman ('Specification tests') test shows that the random-effect model is more efficient than the fixed-effects model, but the two models do not differ systematically. In this case, the standard solution is to investigate the correlation between individual effects and regressors directly. The results obtained in these tests lead us to accept the null hypothesis of non-correlation in all the models estimated, at any significance level. Hence, the choice has been to estimate random-effects models. Unfortunately, results (not presented here, but available from the author) were practically identical to those obtained with standard techniques, perhaps due to the fact that the maximum number of observations for each firm is small (two).

${ }^{94}$ Alternative specifications combining both spinning and weaving panels and employing interaction terms have also been tested without significantly different results (all estimations are available upon request).
} 
Table 6. Determinants of vertical integration in cotton spinning and weaving

\begin{tabular}{|c|c|c|c|}
\hline \multirow{2}{*}{$\begin{array}{l}\text { Dependent variable } \\
\text { Method }\end{array}$} & \multicolumn{2}{|c|}{ Vertical integration $=1 ; 0$ otherwise } & \multirow{2}{*}{$\begin{array}{c}\text { Cloth (yarn) production } \\
\text { Yarn (cloth) production } \\
\text { Tobit }\end{array}$} \\
\hline & Logit & Logistic & \\
\hline \multicolumn{4}{|l|}{ Panel A: spinning } \\
\hline Constant & $\begin{array}{r}-8.7712^{\mathrm{a}} \\
(1.3429)\end{array}$ & & \\
\hline Concentration & $\begin{array}{r}1.5255^{\mathrm{a}} \\
(0.3009)\end{array}$ & $\begin{array}{r}4.5976^{\mathrm{a}} \\
(1.3838)\end{array}$ & $\begin{array}{l}1.3168^{\mathrm{a}} \\
(0.2951)\end{array}$ \\
\hline Size & $\begin{array}{r}0.3662^{\mathrm{a}} \\
(0.0983)\end{array}$ & $\begin{array}{r}1.4424^{\mathrm{a}} \\
(0.1418)\end{array}$ & $\begin{array}{r}0.4694^{\mathrm{a}} \\
(0.1003)\end{array}$ \\
\hline Modern machinery & $\begin{array}{r}-0.2478^{\mathrm{b}} \\
(0.0734)\end{array}$ & $\begin{array}{r}0.7804^{\mathrm{b}} \\
(0.0573)\end{array}$ & $\begin{array}{r}0.0096^{\mathrm{d}} \\
(0.0770)\end{array}$ \\
\hline Log likelihood & -368.88 & -368.88 & -425.53 \\
\hline $\mathrm{Chi}^{2}$ & 40.79 & 40.79 & 88.72 \\
\hline Pseudo $\mathrm{R}^{2}$ & 0.05 & 0.05 & 0.09 \\
\hline Observations & 608 & 608 & 608 \\
\hline \multicolumn{4}{|l|}{ Panel B: weaving } \\
\hline Constant & $\begin{array}{r}-8.9870^{\mathrm{a}} \\
(1.4039)\end{array}$ & & $\begin{array}{r}-6.8906^{\mathrm{a}} \\
(1.5708)\end{array}$ \\
\hline Concentration & $\begin{array}{r}1.5121^{\mathrm{a}} \\
(0.2794)\end{array}$ & $\begin{array}{r}4.5363^{\mathrm{a}} \\
(1.2381)\end{array}$ & $\begin{array}{l}1.1608^{\mathrm{a}} \\
(0.3002)\end{array}$ \\
\hline Size & $\begin{array}{l}0.09829^{\mathrm{d}} \\
(0.1164)\end{array}$ & $\begin{array}{r}1.1033^{\mathrm{d}} \\
(0.1284)\end{array}$ & $\begin{array}{c}-0.0958^{\mathrm{d}} \\
(0.1193)\end{array}$ \\
\hline Modern machinery & $\begin{array}{r}0.7335^{\mathrm{a}} \\
(0.0824)\end{array}$ & $\begin{array}{r}2.0824^{\mathrm{a}} \\
(0.1718)\end{array}$ & $\begin{array}{r}0.9296^{\mathrm{a}} \\
(0.1306)\end{array}$ \\
\hline Log likelihood & -332.26 & -332.26 & -463.57 \\
\hline $\mathrm{Chi}^{2}$ & 406.38 & 406.38 & 335.36 \\
\hline Pseudo $\mathrm{R}^{2}$ & 0.38 & 0.38 & 0.27 \\
\hline Observations & 1,416 & 1,416 & 1,416 \\
\hline
\end{tabular}

Notes: $a$ significant at 0.01 level; $b$ significant at 0.05 level; $c$ significant at 0.1 level; $d$ not significant.

Standard errors are in parentheses. All explanatory variables are in logs. Yearly dummies are included in all regressions. The concentration variable is a geometric average of the concentration ratios in the cotton spinning sector and cotton weaving in a given district. This follows Caves and Bradburd ('Empirical determinants', pp. 269-70), who recommend estimating joint seller and buyer market concentration in each market. These concentration ratios are obtained as the ratio between the (estimated) production capacity of the largest four firms of that district and the total (estimated) production capacity of that district. ${ }^{93}$ In panel A, size is measured as the production capacity in tons of yarn per year and modern machinery is measured as the ratio of the estimated production of yarn made by steam and water-powered machinery to the total estimated production of yarn. In panel $\mathrm{B}$, size is measured as the production capacity in tons of cloth per year and modern machinery is measured as the ratio of the estimated production of cloth made by power looms to the total estimated production of cloth.

Sources: See tab. 1.

therefore, that vertical integration advanced as a backward integration of powerloom weaving into mechanical spinning.

It is also interesting to explore whether the integration behaviour of recently established cotton firms differed from that of established firms. The period of entry was 11 years (from 1850 to 1861). Table 7 presents the results of an analysis of the probability of integration and the extent of internal markets separately for firms that were new in the sample year of 1861 and for established firms that had been operating in the previous sample year. ${ }^{95}$ The models are the same as those estimated in table 6 and were estimated only for firms operating in 1861. It is

\footnotetext{
${ }^{93}$ Alternative measures of concentration were also tested, such as the total amount of production capacity of the district, the total production capacity of yarn or cloth, and the concentration ratio of the upward (backward) sector, without significantly different results in the regressions. All of these alternative estimations are available upon request from the author.

${ }^{95}$ Ohanian ('Vertical integration', p. 206) suggests this test.
} 
Table 7. Determinants of vertical integration in cotton spinning and weaving: entrants versus established firms

\begin{tabular}{|c|c|c|c|c|}
\hline \multirow{2}{*}{$\begin{array}{l}\text { Sample } \\
\text { Method }\end{array}$} & \multicolumn{2}{|c|}{ Entrants } & \multicolumn{2}{|c|}{ Established } \\
\hline & Logit & Tobit & Logit & Tobit \\
\hline \multirow[t]{2}{*}{ Constant } & $10.1119^{\mathrm{a}}$ & $4.4843^{\mathrm{a}}$ & $12.0606^{\mathrm{a}}$ & $2.8647^{\mathrm{a}}$ \\
\hline & $(1.5288)$ & $(0.6129)$ & (3.5333) & $(0.9772)$ \\
\hline \multirow[t]{2}{*}{ Concentration } & $1.4711^{\mathrm{a}}$ & $0.0269^{\mathrm{a}}$ & $1.7807^{\mathrm{b}}$ & $0.0297^{a}$ \\
\hline & $(0.3458)$ & $(0.0072)$ & $(0.7664)$ & $(0.0063)$ \\
\hline \multirow[t]{2}{*}{ Size } & $0.2536^{\mathrm{b}}$ & $0.0023^{c}$ & $0.4041^{\mathrm{d}}$ & $0.0024^{\mathrm{d}}$ \\
\hline & $(0.1042)$ & $(0.0014)$ & $(0.2372)$ & $(0.0022)$ \\
\hline \multirow[t]{2}{*}{ Modern machinery } & $0.4302^{\mathrm{a}}$ & $0.0269^{\mathrm{a}}$ & $0.3764^{\mathrm{a}}$ & $0.0239^{a}$ \\
\hline & $(0.0692)$ & $(0.0039)$ & $(0.1423)$ & $(0.0072)$ \\
\hline Log likelihood & 277.2565 & 389.8194 & 60.7414 & 91.4793 \\
\hline $\mathrm{Chi}^{2}$ & 169.26 & 161.66 & 46.91 & 47.30 \\
\hline Pseudo $\mathrm{R}^{2}$ & 0.2290 & 0.1717 & 0.2625 & 0.2054 \\
\hline Observations & 637 & 637 & 140 & 140 \\
\hline
\end{tabular}

Notes: $a$ significant at 0.01 level; $b$ significant at 0.05 level; $c$ significant at 0.1 level; $d$ not significant. Standard errors are in brackets. All estimations comprise observations in cotton spinning and weaving (sector dummies are included in the regressions). The dependent variable in logit estimations is Vertical integration $=1,0$ otherwise. The dependent variable in Tobit regressions is Cloth (yarn) production/Yarn (cloth) production.

Sources: See tab. 1.

remarkable that the test in both logit and Tobit estimations suggests that there are no significant differences between new and established firms. ${ }^{96}$ This implies that even established firms were reactive to changes in market circumstances, particularly the increase in levels of concentration.

\section{IV}

The objective of this section is to apply the intuitions behind the model outlined above to other phases in the production and distribution of cotton textiles. More specifically, it will speculate about the relevance of the independent variables (concentration, size, and modern machinery) in explaining the limited scope of vertical integration in cotton printing, raw cotton markets, and finished cloth markets.

Why was vertical integration so limited in cotton printing? Interestingly, cotton printing firms in Catalonia shared several characteristics with vertically integrated firms in cotton spinning and weaving, but there were also significant differences.

\footnotetext{
${ }^{96}$ The method for comparing logit coefficients across groups was developed by Allison, 'Comparing logit and probit'. There are two strategies. The first strategy is to separate the sample into subgroups, then perform an otherwise identical logistic regression for each. One then computes the p value for a Wald chi-square test of the significance of the differences between the corresponding coefficients. The second strategy is to create an indicator (dummy) variable or set of variables which reflects membership/non-membership in the group and also to have interaction terms between the indicator dummies and other independent variables, so that the significant interactions are interpreted as indicating significant differences across groups for the corresponding independent variables. When an indicator variable has been entered as a set of dummy variables, its interaction with another variable will involve multiple interaction terms. In this case, the significance of the interaction of the indicator variable and another independent variable is the significance of the change of R-square of the equation with the interaction terms and the equation without the set of terms associated with the ordinal variable. These two tests served to reject clearly the existence of cross-group differences. However, it should be noted that Allison's test is conservative, in that it will always yield a chi-square which is smaller than the conventional test, making it harder to prove the existence of cross-group differences.
} 
Size and the production of longer series were characteristics shared by cotton printing and vertically integrated cotton spinning and weaving firms. The average production capacity of cotton printing firms was 131 tons in 1850 and 223 tons in 1861 ; that is, several times the average capacity of cotton spinning and weaving firms. Moreover, the 10 largest cotton printing firms had a greater production capacity (measured in tons) than the 10 largest cotton spinning or weaving firms. Consequently, at first sight, size may justify the costs of internal organization and make backward vertical integration of cotton printing firms into cotton weaving desirable. However, the extent of vertical integration among these largest cotton printing firms was limited; so, in 1861, only three of 10 firms vertically integrated cotton printing with cotton weaving. ${ }^{97}$ Moreover, as in cotton spinning and weaving, modern printing firms produced longer series of each type of cloth than traditional firms; therefore, apparently, they could suffer from dedicated assets problems.

However, printing firms also differed significantly in other ways. Firstly, they did not suffer the physical asset problems of power-loom weaving firms, since modern printing machinery could use any kind of cotton cloth regardless of quality, which was easily measured by any expert. ${ }^{98}$ Secondly, in spite of the fact that the overall (region-wide) concentration of the cotton printing phase was the highest, ${ }^{99}$ the concentration level of the firms by district was relatively low. Catalan cotton printing firms were concentrated in only two locations: the majority of firms were located in Barcelona (particularly in the borough of Sant Martí de Provençals) and the rest in the Anoia cotton district (mainly in the town of Igualada). ${ }^{100}$ In other words, weaving firms did not experience small-numbers bargaining problems when selling their grey cloth to printing firms or when subcontracting printing processes. Moreover, given the structure of the distribution of cloth in Catalonia, printing firms did not suffer from this kind of problem either. Cotton cloth was produced elsewhere in Catalonia, but was normally transported to Barcelona for distribution, and most cotton-weaving firms had a storehouse in the city. In other words, the supply of grey cloth in Barcelona was continuous, far exceeding the production capacity of the city and its surroundings. In summary, the preponderance of specialized firms in cotton printing can be explained by appealing to the lack of importance of asset specificity in printing production. ${ }^{101}$

It is remarkable to note that similar arguments can be used to explain the low levels of backward integration of cotton firms into the supply of raw cotton and forward integration into the distribution of finished cloth. In the first case, the quality of raw cotton could be recognized easily by any expert, since it depended on the physical, observable characteristics of the fibre. Moreover, in Barcelona there were many wholesale merchants capable of maintaining a continuous flow of raw cotton at competitive prices. For example, the largest individual consumer of raw cotton in Catalonia, the España Industrial SA, chartered ships to transport

\footnotetext{
${ }^{97}$ Similarly, of the 10 largest cotton-weaving firms, only three integrated forward into cotton printing.

${ }^{98}$ Comisión Especial Arancelaria, Información.

${ }^{99}$ This was mainly due to the fact that the number of firms was much smaller than in the other phases.

${ }^{100}$ For example, by 1850,49 of 57 printing firms were located in the district of Barcelona, and in 1861 this proportion grew, since 37 of 42 were located there.

${ }^{101}$ It should be noted that regressions similar to those in tab. 5 employing cotton-finishing data have been estimated without any significant result.
} 
raw cotton from New Orleans in the late 1850s, but quickly decided to give up this practice as no savings at all were made. ${ }^{102}$

In the case of finished fabrics marketing, a large number of wholesalers, merchants, and agents who traded with cotton goods were also located in Barcelona. Commonly, these merchants were responsible for all the distribution of Catalan cloth throughout Spain, although they sometimes received credit from cotton industry firms. Therefore, it was relatively easy for any cotton firm to change to a different merchant; in other words, the small-number bargaining problem was of little importance in the distribution of finished cloth. More significantly, it was common for the largest firms in the cotton industry to trade with a large number of merchant-houses (sometimes more than 50). ${ }^{103}$

\section{$\mathrm{V}$}

This article offers new insights into the causes of vertical integration and subcontracting in the Spanish cotton industry by applying some of the arguments of transaction cost theory. The use of vertical integration was more widespread in yarn markets characterized by relatively high buyer and seller concentration. Larger cotton spinning and weaving firms and those employing the most recent technology (self-acting mules and power-looms) were also more likely to integrate vertically because of physical and dedicated assets problems. Subcontracting, however, predominated in phases such as cotton printing and the marketing of raw cotton and finished cotton goods, where small-numbers bargaining problems were minor and where asset specificity problems were less important. Consequently, vertical integration was not the result of any general characteristic of the Spanish market for cotton goods, but of some specific characteristics of the intermediate markets for yarn. ${ }^{104}$

These results suggest some sort of evolutionary interpretation of the changes in the market structure of the cotton industry in Catalonia over the eighteenth and nineteenth centuries, in accordance with the life-cycle theory advanced by Stigler. ${ }^{105}$ However, the evidence also indicates that the evolution of the structure of the industry was shaped by forces other than asset specificity. Particularly relevant is the role of the institutional and legal framework during the earlier development of the industry.

In the early days of the industry, as Thompson has argued, the predominance of vertical integration into weaving and marketing among calico printing concerns was probably caused by the particular institutional framework which emerged from local traditions and the subsequent regulation introduced by the Bourbon governments. ${ }^{106}$ The absolute dominance of the guild system in Barcelona, which limited the extent of the market, had made the organization of the weaving industry on a putting-out basis virtually impossible in these early years. Therefore,

\footnotetext{
${ }^{102}$ See Castañeda and Tafunell, 'Mercado mayorista', on this market.

${ }^{103}$ See Prat and Soler, 'Formación de redes comerciales'.

${ }^{104}$ Note that this result contradicts previous research (Maluquer, 'Estructura') which stressed that, given the characteristics of the Spanish home market (small and unstable), the only choice for Catalan cotton firms was subcontracting.

${ }^{105}$ Stigler, 'Division of labor'.

${ }^{106}$ Thompson, Distinctive industrialisation.
} 
there were not enough independent handloom weavers and merchants to satisfy the buyer and seller necessities of the relatively large printing concerns. Moreover, government mercantilist regulations forced calico printing concerns to integrate into spinning and weaving. In 1767, the same industry adopted regulations in order to protect this type of industrial structure based on relatively large calico printing concerns which were vertically integrated into spinning and weaving.

The reliance of cotton firms on vertical integration decreased from the $1790 \mathrm{~s}$ onwards. It is likely that this change was caused by the interaction of several forces. Firstly, the changing political circumstances eroded the power of guilds and the previous set of regulations. Secondly, the industry grew enough to maintain specialized firms in both cotton weaving and printing. Thirdly, the new cotton spinning industry was vertically specialized because it was made up of relatively small units of production. Fourthly, cotton industry machinery made production in small batches (to order) possible. In other words, asset specificity problems (particularly physical assets and dedicated assets) appear to have been minor during this period. Finally, given the high levels of uncertainty and the low levels of asset specificity, vertical specialization was efficient at coping with the unstable demand given the low contracting costs. ${ }^{107}$

The situation changed dramatically with the arrival of the factory system and the new self-acting mules, throstles, and power-looms. These new technologies were less flexible than the older machinery and produced longer series of each type of yarn and cloth; thus, cotton mills grew in size and put pressure on local markets for yarn. For this reason, dedicated, physical, and site specificity problems arose, and new entrants to the field of cotton spinning and weaving decided to integrate these two consecutive phases vertically. It is likely that this situation continued over the rest of the century, given that the average mean size of cotton mills grew and the industry continued to survive in many locations, due to the increase in the number of water mills. ${ }^{108}$

How do these results for Spain compare with previous studies for other countries? It is clear that the Spanish experience has some important similarities with the experiences of other countries, and this research may serve to throw light on some hitherto unclear issues. Previous studies of the cotton industries in Lancashire, the United States, and Germany have found that size, product type (coarse goods), and location were major determinants of the vertical integration of cotton

\footnotetext{
${ }^{107}$ The literature on transaction costs argues that uncertainty is relevant for vertical integration if a certain degree of asset specificity exists. If a transaction does not require specific investments, contracting costs are small and a new agreement could be reached easily in any new situation. Instead, when asset specificity exists, uncertainty increases the cost of establishing how the participants should act in each possible contingency and makes the existence of unforeseen hold-up problems possible. On this point, see, for example, Williamson, Economic institutions, pp. 56-60.

${ }^{108}$ Unfortunately, the quality of cotton industry statistics decreased sharply after the cotton famine, although qualitative evidence on the abundance of vertically integrated firms during the second half of the nineteenth century is abundant (see, for example, Nadal, 'Indústria cotonera', pp. 48-57). Moreover, the accounts for the early twentieth century show the preponderance of vertically integrated mills in Catalonia. For example, Odell (Cotton goods, p. 17), in his study for the industry in 1911, pointed out: 'The (Catalan cotton) industry is modelled after that of the United States, spinning, weaving and finishing being carried on in each mill. In addition, many of the plants maintain complete bleaching and printing departments which enable them to furnish the finished product to the trade.' Similarly, the survey conducted in 1929 by the comité regulador de la industria algodonera (Regulatory Committee of the Cotton Industry). (Beltrán, Industria algodonera, p. 158) found that 58\% of spinning firms were integrated into weaving.
} 
spinning and weaving. ${ }^{109}$ It appears that the greater tendency of bigger spinning and weaving firms to vertically integrate, compared to smaller firms, is a universal pattern.

Product type is directly related to the choice of machinery, given that the self-acting mules and the power-looms were better suited to the production of coarser than finer goods. ${ }^{110}$ Consequently, the variable machinery of this study can be considered practically equivalent to the variable quality of previous studies. In other words, it would also appear that certain types of machinery which were employed to produce coarse goods paved the way to vertical integration, given their asset specificity problems.

In spite of the fact that all of these studies have considered the relative importance of location variables, they have rarely linked this relevance to the presence of small-number bargaining problems. ${ }^{111}$ This article offers a straightforward explanation for the relevance of location in the choice between vertical integration and market governance. Districts with high concentration ratios suffered from smallnumbers bargaining problems and, hence, had a large share of vertically integrated firms. This argument could be used to explain why the English cotton industry was vertically specialized and the US and German cotton industries were vertically integrated. In Lancashire, the concentration of cotton firms of different phases in a short distance was extraordinary. In contrast, cotton firms in Spain, the United States, and Germany were typically spread out or even isolated from other firms. Consequently, it is not surprising that they suffered from small-numbers bargaining problems and faced large transaction and transport costs when changing supplier or buyer. Finally, at least in Catalonia, there was no direct correlation between shop-floor organization and business organization. More specifically, vertically integrated firms (and horizontally specialized firms) could employ the two major types of labour management practices: foremanship and internal subcontracting. It seems that the kind of job and workforce skills, rather than the type of firm, were the major determinants of workforce organization.

To conclude, I would like to highlight three broad suggestions for further research. Firstly, the evidence collected here indicates the importance of high concentration ratios and the subsequent small-numbers bargaining problems in firms' choices regarding vertical integration. Consequently, it would be desirable to extend the evidence on market concentration to cotton industries in other countries. Secondly, the article's findings suggest the need to rethink the relationship between vertical integration and international competitiveness. In line with Brown's study of the situation in Germany, the results obtained here support the view that there was no close connection between vertical integration and success-

\footnotetext{
${ }^{109}$ Huberman, 'Vertical disintegration'; Temin, 'Product quality'; Brown, 'Market organization'.

${ }^{110}$ Obviously, the choice of quality is also related to the characteristics of markets. In the case of Spain, the highly protected cotton industry produced goods for domestic consumers who were relatively poor and preferred cheap and durable cotton goods; that is, relatively heavy cloth. However, in the case of Spain (in sharp contrast with the US experience; see Scranton, Proprietary capitalism, pp. 44ff.) the characteristics of local markets did not determine the pattern of specialization. For example, without discernible differences in consumer demand, the city of Reus specialized mainly in fine goods, whereas the city of Vilanova specialized in heavy goods. In Barcelona, all types of cotton textiles were produced.

${ }^{111}$ Leunig's article ('New answers') on the Lancashire cotton industry during the early twentieth century provides a notable exception to this rule. He argues that spinning firms did not suffer hold-ups because, given the high spatial concentration of the industry, there was enough upstream competition.
} 
fulness in international markets for cotton goods. ${ }^{112}$ Thirdly, this article has shown the explanatory power, and some limitations, of the transaction cost theory in economic and business history. In a dynamic framework, factors such as demand, traditions, institutions, and legal framework, as well as asset specificity, appear to be relevant in shaping business structures. Consequently, a historically sounded explanation for vertical integration should take into account all of these dynamic factors, not just the static properties of business transactions that are analysed by transaction cost theory.

\title{
Universidad Carlos III de Madrid
}

\author{
Date submitted \\ Revised version submitted \\ Accepted
}

\author{
19 March 2005 \\ 1 fune 2006 \\ 30 August 2007
}

DOI: $10.1111 /$ j.1468-0289.2008.00428.x

${ }^{112}$ Brown, 'Market organization'.

\section{Footnote references}

Allison, P. D., 'Comparing logit and probit coefficients across groups', Sociological Methods and Research, 28 (1999), pp. 186-208.

Arau, N., Tratado completo de la hilatura del algodón (Barcelona, 1855).

Beltrán, L., La industria algodonera española (Barcelona, 1943).

Brown, J. C., 'Market organization, protection, and vertical integration: German cotton textiles before 1914', fournal of Economic History, 52 (1992), pp. 339-51.

Castañeda, L. and Tafunell, X., 'El mercado mayorista del algodón en Barcelona a mediados del siglo XIX', in A. Carreras, J. Pascual, D. Reher and C. Sudrià, eds., Doctor fordi Nadal. La Industrialització i el Desenvolupament Econòmic d'Espanya, 2. (Barcelona, 1999), pp. 990-1005.

Caves, R. E. and Bradburd, R. M., 'The empirical determinants of vertical integration', fournal of Economic Behaviour and Organization, 9 (1988), pp. 265-79.

Clark, G., 'Why isn't the whole world developed? Lessons from the cotton mills', fournal of Economic History, 47 (1987), pp. 141-73.

Coase, R. H., 'The nature of the firm', Economica, 4 (1937), pp. 33-55.

Delgado, J. M., 'Mercado interno versus mercado colonial en la primera industrialización española', Revista de Historia Económica, 13 (1995), pp. 11-31.

Farnie, D. A., The English cotton industry and the world market, 1815-1896 (Oxford, 1979).

Ferrer Alós, L., 'Bergadanas, contínuas y mules. Tres geografías de la hilatura del algodón en Cataluña (1790-1830)', Revista de Historia Económica, 22 (2004), pp. 337-86.

Ferrer Vidal, J., Conferencias sobre el arte de hilar y tejer en general y especialmente sobre el de hilar y tejer el algodón (Barcelona, 1875).

Figuerola, L., Estadistica de Barcelona en 1849 (Madrid, 1968).

García Balañà, A., La fabricació de la fàbrica. Treball i política a la Catalunya cotonera (1784-1874) (Barcelona, 2004).

Gatrell, V. A. C., 'Labour, power, and the size of firms in Lancashire cotton in the second quarter of the nineteenth century', Economic History Review, 2nd ser., XXX (1977), pp. 95-139.

Giménez Guited, F., Guia fabril e industrial de España. publicada con el apoyo y autorización del gobierno de SM (Madrid and Barcelona, 1862).

González-Díaz, M., Arruñada, B. and Fernández, A., 'Causes of subcontracting: evidence from panel data on construction firms', fournal of Economic Behaviour and Organization, 42 (2000), pp. 167-87.

Graell, G., Informació pública sobre la necessitat de crear una banca catalana (Barcelona, 1908).

Grau, R. and López, M., 'Empresari i capitalista a la manufactura catalana del segle XVIII. Introducció a l'estudi de les fabriques d'indianes', Recerques, 4 (1974), pp. 19-57.

Greene, W. H., Econometric analysis (New York, 1993).

Grossman, S. and Hart, O., 'The costs and benefits of ownership: a theory of vertical and lateral integration', fournal of Political Economy, 94 (1986), pp. 691-719.

Gutiérrez, M. M., Impugnación a las cinco proposiciones de Pebrer sobre los grandes males que causa la ley de aranceles a la nación en general. a la Cataluña en particular, y a las mismas fábricas catalanas (Madrid, 1837). 
Hausman, J., 'Specification tests in econometrics', Econometrica, 46 (1978), pp. 1251-71.

Huberman, M., 'Vertical disintegration in Lancashire: a comment on Temin', fournal of Economic History, 50 (1990), pp. 683-90.

Jeremy, D. J., 'Organization and management in the global cotton industry, 1800s-1990s', in D. A. Farnie and D. J. Jeremy, eds., The fibre that changed the world. The cotton industry in international perspective, 1600-1990s (Oxford, 2004), pp. 191-245.

Joskow, P. L., 'Contract duration and relationship-specific investments: empirical evidence from coal markets', American Economic Review, 77 (1987), pp. 168-85.

Joskow, P. L., 'Vertical integration', in C. Menard and M. Shirley, eds., Handbook of new institutional economics (Amsterdam, 2005), pp. 319-20.

Klein, B., Crawford, R. and Alchian, A., 'Vertical integration, appropriable rents, and the competitive contracting process', fournal of Law and Economics, 21 (1978), pp. 297-326.

Klein, P. G., 'The make-or-buy decision: lessons from empirical studies', in C. Menard and M. Shirley, eds., Handbook of new institutional economics (Amsterdam, 2005), pp. 435-69.

Lazonick, W., 'Industrial organization and technological change: the decline of the British cotton industry', Business History Review, 57, 2 (1983), pp. 195-236.

Leunig, T., 'New answers to old questions: explaining the slow adoption of ring spinning in Lancashire, 1880-1913', Fournal of Economic History, 61 (2001), pp. 439-66.

Lyons, J. S., 'Vertical integration in the British cotton industry, 1825-1850: a revision', fournal of Economic History, 45 (1985), pp. 419-25.

Lyons, J. S., 'Powerloom profitability and steam power costs', Explorations in Economic History, 24 (1987), pp. 397-400.

MacDonald, J. M., 'Market exchange or vertical integration: an empirical analysis', Review of Economics and Statistics, 67 (1985), pp. 327-31.

Madoz, P., Diccionario geográfico-estadístico-histórico de España y sus posesiones de ultramar (Madrid, 1846).

Maluquer de Motes, J., 'La estructura del sector algodonero en Cataluña durante la primera etapa de la industrialización (1832-1861)', Hacienda Pública Española, 38 (1976), pp. 133-48.

Mass, W. and Lazonick, W., 'The British cotton industry and international competitive advantage: the state of the debates', Business History, 32, 4 (1990), pp. 9-65.

Mowery, D. C., 'Finance and corporate evolution in five industrial economies, 1900-1950', Industrial and Corporate Change, 1 (1992), pp. 1-36.

Nadal, J., El fracaso de la Revolución Industrial en España (Barcelona, 1974).

Nadal, J., 'La indústria cotonera', in J. Nadal, J. Maluquer de Motes and F. Cabana, eds., Història Económica de la Catalunya contemporània, 3 (Barcelona, 1991), pp. 12-85.

Nadal, J. and Tafunell, X., Sant Martí de Provençals, pulmó industrial de Barcelona (1847-1992) (Barcelona, 1992).

Odell, R. M., Cotton goods in Spain and Portugal (Washington D.C., 1911).

Ohanian, N. K., 'Vertical integration in the US pulp and paper industry, 1900-1940', Review of Economics and Statistics, 74 (1994), pp. 202-7.

Orellana, F. J., Reseña completa descriptiva y crítica de la Exposición Industrial y Artística de Productos del Principado de Cataluña improvisada en Barcelona para obsequiar a S.M. La Reina Doña Isabel II (Barcelona, 1860).

Perry, M. K., 'Vertical integration: determinants and effects', in R. Schmalensee and R. D. Willig, Handbook of industrial organization, 1 (Amsterdam, 1989), pp. 183-255.

Prados de la Escosura, L., 'Producción y consumo de tejidos en España, 1800-1913: primeros resultados', in G. Anes, L. A. Rojo and P. Tedde, eds., Historia económica y pensamiento social (Madrid, 1983), pp. 455-71.

Prat, M. and Soler, R., 'La formación de redes comerciales y el fracaso de la penetración internacional de los tejidos catalanes, 1850-1930', Revista de Historia Industrial, 21 (2002), pp. 201-25.

Ronquillo, J. O., Diccionario de materia mercantil, industrial y agricola (Barcelona, 1851-7).

Rose, M. B., Firms, networks and business values. The British and American cotton industries since 1750 (Cambridge, 2000).

Rosés, J. R., 'The choice of technology in the Mediterranean basin', in S. Pamuk and J. D. Williamson, The Mediterranean response to globalization (2000), pp. 134-56.

Rosés, J. R., 'La competitividad internacional de la industria algodonera catalana', Revista de Historia Económica, 19 (2001), pp. 85-109.

Rosés, J. R., 'Industrialización regional sin crecimiento nacional: la industrialización catalana y el crecimiento de la economía española (1830-1861)', Revista de Historia Industrial, 25 (2004), pp. 49-80.

Sánchez, A., 'La era de la manufactura algodonera en Barcelona, 1736-1839', Estudios de Historia Social, 48-9 (1989), pp. 65-113.

Sánchez, A., 'La indianeria catalana: ¿Mito o realidad?', Revista de Historia Industrial, 1 (1992), pp. $213-32$.

Sánchez, A., 'Crisis económica y respuesta empresarial. Los inicios del sistema fabril en la industria algodonera catalana, 1797-1839', Revista de Historia Económica, 18 (2000), pp. 485-524.

Sayró, E., Industria algodonera de Cataluña (Madrid, 1842).

Scranton, P., Proprietary capitalism: the textile manufacture at Philadelphia, 1800-1885 (Cambridge, 1984).

Shelanski, H. A. and Klein, P. G., 'Empirical research in transaction cost economics: a review and assessment', Fournal of Law, Economics and Organization, 11 (1995), pp. 335-61. 
Sicsic, P., 'Establishment size and economies of scale in 19th-century France', Explorations in Economic History, 31 (1994), pp. 453-78.

Solà Parera, À., Aigua, indústria i fabricants a Manresa (1759-1860) (Manresa, 2004).

Stigler, G. J., 'The division of labor is limited by the extent of the market', fournal of Political Economy, 59 (1951), pp. 185-93.

Taylor, A. J., 'Concentration and specialization in the Lancashire cotton industry, 1825-1850', Economic History Review, 2nd ser., I (1949), pp. 114-22.

Temin, P., 'Product quality and vertical integration in the early cotton textile industry', fournal of Economic History, 48 (1988), pp. 891-907.

Thompson, J. K. J., A distinctive industrialisation. Cotton in Barcelona: 1728-1832 (Cambridge, 1992).

Thompson, J. K. J., 'Technological transfer to the Catalan cotton industry: from calico printing to the self-acting mule', in D. A. Farnie and D. J. Jeremy, eds., The fibre that changed the world. The cotton industry in international perspective, 1600-1990s (Oxford, 2004), pp. 249-82.

von Tunzelmann, G. N., Steam power and British industrialization to 1860 (Oxford, 1978).

Williamson, O. E., Markets and hierarchies: analysis and antitrust implications (New York, 1975).

Williamson, O. E., The economic institutions of capitalism (New York, 1985).

Williamson, O. E., The mechanisms of governance (New York, 1996).

\section{Official publications}

Comisión Especial Arancelaria, Información sobre el derecho diferencial de bandera y sobre los de aduanas exigibles a los hierros, al carbón de piedra y los algodones, presentada al gobierno de Su Majestad por la comisión nombrada de efecto en Real Decreto de 10 de Noviembre de 1865 (Madrid, 1867).

\section{APPENDIX: ESTIMATING THE PRODUCTION CAPACITY OF COTTON FIRMS}

The sources for this article are the two major surveys carried out during the period for the Catalan cotton industry. The survey of 1850 (Junta de Fabricas de Cataluña, Censo de fabricas de 1850, Arxiu del Foment del Treball Nacional, Barcelona) is divided into three parts: the first focusing on cotton spinning establishments, the second on cotton and mixed-fabric weaving establishments, and the third on printing establishments. The survey appears to include establishments located in all parts of Catalonia. For each category, the survey lists the name of the firm, the location of the establishment, the amount and type of machinery in use, and number of workers. The industrial guide for 1861 (Gimenez Guited, Guia fabril) collected data on all cotton firms located in Catalonia. It seems that the original data were drawn from records of industrial taxes and were similar to the information collected in the previous survey. However, unlike the census for 1850 , this survey did not separate workers from the different phases since it aggregated them by establishment and firm.

These two surveys did not record data regarding the actual production of each firm. However, given that different types of spindles and looms produced different amounts of product per year, the production capacity in tons per year of each firm can be derived from the machinery figures. According to the sources, the average production capacity of the different types of spindles were as follows: $3 \mathrm{~kg}$ per year for hand-spindles; $11 \mathrm{~kg}$ per year for mule-jennies powered by horses; $15 \mathrm{~kg}$ per year for throstles; $20 \mathrm{~kg}$ per year for steam- or water-powered mule-jennies; and $23 \mathrm{~kg}$ per year for self-acting mules. Similarly, the average production capacity of hand-looms was $280 \mathrm{~kg}$ per year and that of power-looms was $1,400 \mathrm{~kg}$ per year. The sources of these figures are Sayró, Industria algodonera, Figuerola, Estadística, and Comisión Especial Arancelaria, Información, vol. IV, pp. 43-54.

Using estimated production figures, the coverage of the sample can be computed by dividing the corresponding values (collected in tab. 1) by the amount of yarn and cloth production in Rosés ('Industrialización regional', pp. 74-5). Thus, 
in 1850 the coverage of cotton spinning was 99.77 per cent, and of cotton weaving 93.89 per cent; in 1861 the figure for cotton spinning was 94.75 per cent, and 95.74 per cent for cotton weaving.

Table A1. Descriptive statistics of the variables

\begin{tabular}{|c|c|c|c|c|c|c|}
\hline & \multicolumn{3}{|c|}{1850} & \multicolumn{3}{|c|}{1861} \\
\hline & Obs. & Mean & $S D$ & Obs. & Mean & $S D$ \\
\hline \multicolumn{7}{|l|}{ Panel A: spinning } \\
\hline Dep. var. & 314 & 0.2812 & 0.4502 & 256 & 0.4179 & 0.4941 \\
\hline Concentration & 314 & 3.3181 & 0.2208 & 256 & 3.7075 & 0.2207 \\
\hline Size & 314 & 9.5691 & 1.5205 & 256 & 10.4125 & 1.1132 \\
\hline Mod. mach. & 314 & 2.7795 & 2.2620 & 256 & 4.6152 & 0.0000 \\
\hline \multicolumn{7}{|l|}{ Panel B: weaving } \\
\hline Dep. var. & 976 & 0.0719 & 0.2584 & 518 & 0.2146 & 0.4109 \\
\hline Concentration & 976 & 3.3299 & 0.3061 & 518 & 3.6952 & 0.1719 \\
\hline Size & 976 & 8.4513 & 1.1255 & 518 & 9.1201 & 1.2771 \\
\hline Mod. mach. & 976 & 0.2216 & 0.9817 & 518 & 0.9516 & 1.8652 \\
\hline
\end{tabular}

Notes: All explanatory variables in logs. Due to the presence of zeros, the variable modern machinery has been computed as log $(1+$ modern machinery). See tab. 1 . 